\title{
Comparison of body weight and reproduction performance in cows of various beef breeds managed under equal conditions in West Pomerania
}

\begin{abstract}
The aim of the study was to compare the body weight and the parameters of reproductive performance in beef cows of various breeds following their import to Poland from 1995-1997. The analyses included cows of five beef breeds: Red Angus, Salers, Hereford, Limousin and Simmental. We have compared the body weights and calving intervals during the period from their arrival to Poland in 1995 until 2002, with subsequent calvings included in the analyses. Other aspects included calving difficulty, abortions, stillbirths and twin births. The analysis of the cows' reproductive performance has revealed that the studied breeds differ in the calving interval. Best results were achieved by Simmental and Limousine cows, while Red Angus cows exhibited the poorest performance. The effect of subsequent calving on the calving interval was also confirmed. We have observed no differences among the mature cows with respect to the body weight and calving ease.
\end{abstract}

Keywords: beef cattle, breeds, body weight, calving interval, calving ease

\section{Zusammenfassung}

Titel der Arbeit: Vergleich von Körpergewichten und Reproduktionsmerkmalen von Kühen verschiedener Fleischrinderrassen unter einheitlichen Bedingungen in Westpommern

Ziel der Arbeit war der Vergleich von Körpergewicht und Reproduktionsmerkmalen von Kühen verschiedener Fleischrinderrassen aus Importen nach Polen zwischen 1995 bis 1997. Einbezogen waren die Fleischrinderrassen Red Angus, Salers, Hereford, Limousine und Simmental. Im Zeitraum von 1995 bis 2002 wurden bei 549 Kühen das Körpergewicht, die Zwischenkalbezeit und die Merkmale des Geburtsverlaufes - auch bei nacheinander folgenden Abkalbungen - sowie die Zwillingsgeburten erfasst. Bei den Reproduktionsmerkmalen unterschieden sich die verglichenen Rassen hinsichtlich der Zwischenkalbezeit. Die besten Ergebnisse erreichten die Rassen Simmental und Limousine, die schlechtesten die Tiere der Rasse Red Angus. Auch bei den nachfolgenden Geburten bestand ein Einfluss auf die Zwischenkalbezeit. Während die jüngeren Kühe sich hinsichtlich ihres Körpergewichts signifikant unterschieden, war das Gewicht der älteren Kühe relativ ausgeglichen. Beim Geburtsverhalten konnten keine Unterschiede zwischen den verglichenen Rassen nachgewiesen werden.

Schlüsselworte: Fleischrind, Rasse, Körpergewicht, Zwischenkalbezeit, Geburtsverlauf

\section{Introduction}

Beef production in Poland is mostly based on the breeds that are managed for dairy or dairy-beef purposes. Farming the typically beef cattle in Poland has not really started until the beginning of the 1990s, when the "Programme for Beef Cattle Breeding Development in Poland" was implemented. This government strategy involved financial aid for the producers in the form of subsidies and low-interest loans, which soon resulted in an increased import of pure-bred breeding heifers, most often from Europe (France, Denmark, Germany, the Czech Republic and others), but also, to a lesser extent, from the USA and Canada.

Beef cattle breeds represent various biological types, well adapted to various 
environments and production systems representing different feed, climate, land resources and marketing situation. Breed diversity can be used to fit the genetic resources quickly to production and market requirements (FRELICH et al., 1998; GOLCE, 2001; JAKUBEC et al., 2003; DAKAY et al., 2006).

Over the recent decades we have witnessed changes in the utilisation of various breeds in beef production, with intensive selection targeting different traits in different breeds of cattle. Selection of breeds of medium frame sizes puts emphasis on their growth rate rather than calving ease or low body weight at birth, which is the case in the selection of large-frame-size cattle (NÚÑEZ-DOMINGUEZ et al., 1993).

It is a rule in beef cattle management that cows are used only for reproduction and calf nursing. A successful nurse cows management depends mostly on the normal reproduction process, high mean daily gain and total body weight attained by the calf at weaning, as well as the longevity of the cows (ROUGHSEDGE et al., 2001). Good results of reproduction and successful calf rearing underlie the profitability of a beef farm. The herd reproduction parameters, including calving interval and calving ease, have a considerable impact on the financial outcomes of fattening and the management of the breeding stock. Difficulties at parturition represent the major cause of calf mortality and impair both the liveliness of the calf and the milk yield of the dam, while post-partum complications lead to infertility-based culling of the cows.

Identifying superior breeds would be simple if adequate life-cycle performance data were available on large representative samples of the breed of potential interest. Comparisons would need to be made among cattle breeds raised under the same conditions and preferably over a range of conditions to evaluate the possibility of genotype $\times$ environment interactions. Unfortunately, such ideal comparisons require a large input of financial resources (JAKUBEC et al., 2003).

The studied farm applied an equal, outdoor housing system for all the analysed breeds and equal maternal nursing conditions. Moreover, the semen of modern-type bulls (polled Simmental, Limousin and Hereford) has been increasingly used for insemination on the farm. Hence the aim of this study, which was to compare reproductive performance and body weight of cows of various beef breeds over a several years' period following the import of the cows to Poland on a farm where cows are systematically inseminated with the semen of modern-type polled bulls.

\section{Material and methods}

The studies were carried out in West Pomerania at the "Agrofirma Witkowo" Cooperative, where the management system consists in all-year outdoor housing with maximum utilisation of pastures and maternal nursing of calves until the age of 7-9 months.

The analyses included cows of five beef breeds:

- 144 Red Angus (pregnant heifers imported from Canada in December 1995)

- 57 Salers (pregnant heifers imported from Canada in December 1995)

- 70 Hereford (pregnant and non-pregnant heifers imported from Denmark in 1997)

- 105 Limousin (pregnant and yearling heifers imported from France in 1997)

- 173 Simmental (pregnant heifers imported from the Czech Republic in 1996)

The oestrous synchronisation of the cows and heifers took place during the first days of April each year. Artificial insemination was carried out from April until July.

The semen of prime bulls was used to inseminate all breeding cows that exhibited 
symptoms of the normal oestrus. The Red Angus, Hereford and Simmental cows were sired by polled bulls from Canada and the USA, the Salers cows by Canadian bulls, while the Limousin cows by polled bulls from Canada, the USA, and France. In June until mid-July, bulls were included into the herd in order to serve the cows still not in calf. Calvings took place from December until the end of April the following year. Nursing cows were gathered in groups in which the calves were of similar age (less than a month difference) and remained on an enclosure with an access to a shelter against snow or rain. Feeding of the cows (with haylage, hay and mineral supplement) took place outdoors in deep wooden mangers and non-freezing waterers. From May until the end of October, the cows with their calves remained grazing all day, returning to their enclosures for the night. From November onwards, the cows remained on enclosures with wind shelters made of bales of straw. Every day, the animals visited neighbouring fields of oilseed rape or ryegrass. Their grazing diet was supplemented with hay, straw, silage made of conditioned green forage with addition of mineral feed; salt licks were also provided.

The calving intervals were compared over the period between the moment when the animals arrived to Poland and the year 2002, in relation to subsequent calvings. The degree of calving difficulty, percentage of abortions, stillbirths, and twin births were also examined. During the period from the moment of import until 2002, the cows were weighed on each calving (from 1 to 6 ).

Statistical calculations were performed using procedures of STATISTICA PL 7.1. Means and standard deviations were calculated. Two-way ANOVA with interaction in non-orthogonal experimental design was also used. The significance of differences between the groups was tested with the Duncan test. Differences were considered as significant at the level of 0.05 and 0.01 . The following statistical model was used:

$$
\mathrm{y}_{\mathrm{ijk}}=\mu+\alpha_{\mathrm{i}}+\beta_{\mathrm{j}}+(\alpha \beta)_{\mathrm{ij}}+\varepsilon_{\mathrm{ijk}}
$$

where: $y_{\mathrm{ijk}}=$ studied variable, $\mu=$ overall mean, $\alpha_{\mathrm{i}}=$ fixed effect of breed, $\beta_{\mathrm{j}}=$ fixed effect of calvings, $(\alpha \beta)_{\mathrm{ij}}=$ interaction of breed and calvings, $\varepsilon_{\mathrm{ijk}}=$ random error.

\section{Results}

The analysis of the mean cow body weights (Table 1) has demonstrated that the lowest body weight until the $3^{\text {rd }}$ calving was found in the Red Angus cows, while between the $4^{\text {th }}$ and the $6^{\text {th }}$ calving - in the Simmental cows. Intensive body weight gains were recorded from the $3^{\text {rd }}$ calving, which resulted from intensive growth and development of the young cows, whereas the growth between the $4^{\text {th }}$ and the $6^{\text {th }}$ calvings was already low. A significant $(\mathrm{P} \leq 0.01)$ effect of subsequent calving and the breed on the body weight was observed, as well as a significant $(\mathrm{P} \leq 0.01)$ breed $\times$ subsequent calving interaction effect.

The Red Angus cows were of significantly $(\mathrm{P} \leq 0.01)$ lower body weight compared to any of the remaining four breeds after the $1^{\text {st }}, 2^{\text {nd }}$, and $3^{\text {rd }}$ calving. After the $1^{\text {st }}$ and the $2^{\text {nd }}$ calving, the Simmentals were heaviest - their body weights were significantly $(\mathrm{P} \leq 0.01)$ higher than those of the remaining breeds after the first calving and the Red Angus cows $(\mathrm{P} \leq 0.01)$ as well as Salers $(\mathrm{P} \leq 0.05)$ after the $2^{\text {nd }}$ calving. After the $3^{\text {rd }}$ calving, the Hereford cows had the highest body weight, significantly higher than the other breeds. After the $4^{\text {th }}, 5^{\text {th }}$ and $6^{\text {th }}$ calvings, the highest body weights were observed in the Salers cows with significant $(\mathrm{P} \leq 0.01)$ differences, however, observed only after the $4^{\text {th }}$ calving as compared with the Red Angus, Limousin and Simmental cows. The 
Simmental cows were characterised by relatively lowest body weights after the $4^{\text {th }}, 5^{\text {th }}$, and $6^{\text {th }}$ calvings. Their body weights were significantly $(\mathrm{P} \leq 0.05)$ lower compared with the Limousin cows after the $4^{\text {th }}$ calving, Salers and Hereford after the $5^{\text {th }}(\mathrm{P} \leq 0.05)$ and $6^{\text {th }}(\mathrm{P} \leq 0.01)$ calvings, and Red Angus and Limousin after the $6^{\text {th }}$ calving $(\mathrm{P} \leq 0.05)$.

The longest calving intervals (Table 2 ) were observed after the $1^{\text {st }}$ calving, extending for more than 400 days (except for Simmental, 393 days), whereas the shortest - after the 3 rd (from 349 days in Salers to 382 days in Hereford) and the $4^{\text {th }}$ calving (from 366 days for Salers to 374 days for Limousin). The average intervals attained by the Red Angus cows after all subsequent calvings were longer than 400 days or were close to this value (394 days after the $3^{\text {rd }}$ calving).

The distribution of calving difficulties in subsequent calvings was presented in table 3 . The present study observed from $97.3 \%$ (Limousin) to $98.8 \%$ of normal parturitions in the analysed herds. Dystocia was observed in $1.2 \%$ Simmental, $1.4 \%$ Red Angus, $1.8 \%$ Salers and Hereford, and $2.7 \%$ Limousin cows. The highest dystocia rates were recorded in the $1^{\text {st }}$ calving (from 2.5 to $5.8 \%$ of parturitions), with exception for the Hereford cows, where a higher percentage of difficult calvings was observed in the $4^{\text {th }}$, $3^{\text {rd }}$ and $2^{\text {nd }}$ calvings. Abortions happened during the $2^{\text {nd }}(1.3 \%)$ and $4^{\text {th }}(1.7 \%)$ gestations of the Limousin cows, and during the $2^{\text {nd }}(0.9 \%), 3^{\text {rd }}(3.8 \%), 4^{\text {th }}(1.9 \%)$, and $6^{\text {th }}(2.3 \%)$ gestations of the Simmental cows.

In the groups of Red Angus and Salers cows we have not observed any stillbirths or abortions (Table 4), which were otherwise noted in, respectively, $2.8 \%$ and $0.5 \%$ for Hereford, $0.5 \%$ and $0.6 \%$ for Limousin, and $0.2 \%$ and $1 \%$ cases for Simmental.

The highest percentage of twin births was found in the herds of Simmentals, 3.6 \%. In the herds of Red Angus and Hereford, the percentage of twin births was, respectively, $2 \%$ and $1.9 \%$, while Salers and Limousin had $0.6 \%$ twin births each.

Table 1

Mean body weights (in kg) of cows on subsequent calvings (Mittleres Körpergewicht [kg] der Kühe bei nachfolgenden Abkalbungen)

\begin{tabular}{llllllll|llll}
\hline \multirow{2}{*}{ Calvings } & \multicolumn{2}{c}{ Red Angus } & \multicolumn{2}{c}{ Salers } & \multicolumn{2}{c}{ Hereford } & \multicolumn{2}{c}{ Limousin } & \multicolumn{2}{c}{ Simmental } \\
& \multicolumn{1}{c}{ Mean } & SD & Mean & SD & Mean & SD & Mean & SD & Mean & SD \\
\hline 1 & $484.0^{\mathrm{AEFG}}$ & 38.0 & $507.5^{\mathrm{BE}}$ & 24.5 & $504.3^{\mathrm{CF}}$ & 32.7 & $513.9^{\mathrm{DG}}$ & 25.1 & $549.9^{\mathrm{ABCD}}$ & 32.0 \\
2 & $551.7^{\mathrm{ABCD}}$ & 36.2 & $574.4^{\mathrm{Aa}}$ & 38.3 & $588.9^{\mathrm{B}}$ & 43.9 & $586.6^{\mathrm{C}}$ & 51.3 & $594.5^{\mathrm{Da}}$ & 34.3 \\
3 & $595.6^{\mathrm{ADFG}}$ & 40.3 & $618.9^{\mathrm{BEF}}$ & 45.8 & $659.3^{\mathrm{ABCa}}$ & 51.0 & $641.5^{\mathrm{DEa}}$ & 49.5 & $627.6^{\mathrm{CG}}$ & 26.3 \\
4 & $649.5^{\mathrm{AE}}$ & 32.9 & $690.3^{\mathrm{ABC}}$ & 27.6 & $682.2^{\mathrm{EF}}$ & 29.1 & $665.5^{\mathrm{Ba}}$ & 41.4 & $644.9^{\mathrm{CFa}}$ & 28.5 \\
5 & 675.5 & 22.5 & $688.6^{\mathrm{a}}$ & 17.9 & $686.2^{\mathrm{b}}$ & 26.9 & $673.6^{\mathrm{a}}$ & 31.9 & $665.9^{\mathrm{ab}}$ & 19.0 \\
6 & $682.9^{\mathrm{a}}$ & 19.7 & $695.2^{\mathrm{A}}$ & 13.6 & $690.1^{\mathrm{B}}$ & 10.5 & $683.9^{\mathrm{b}}$ & 15.2 & $663.3^{\mathrm{ABab}}$ & 17.0 \\
Total & $575.8^{\mathrm{ABCD}}$ & 79.0 & $595.0^{\mathrm{Da}}$ & 78.2 & $603.3^{\mathrm{C}}$ & 83.6 & $609.6^{\mathrm{Aa}}$ & 74.1 & $605.7^{\mathrm{B}}$ & 51.8 \\
\hline
\end{tabular}

The same upper case letters in rows denote differences significant at $\mathrm{P} \leq 0.01$, the same lower case letters in rows denote differences significant at $\mathrm{P} \leq 0.05$.

Table 2

Mean lengths (in days) of calving intervals after subsequent calvings (Mittlere Zwischenkalbezeit [Tage] der Kühe nachfolgenden Abkalbungen)

\begin{tabular}{llllllll|lll|c}
\hline \multirow{2}{*}{ Calvings } & \multicolumn{2}{c}{ Red Angus } & \multicolumn{2}{c}{ Salers } & \multicolumn{2}{c}{ Hereford } & \multicolumn{2}{c}{ Limousin } & \multicolumn{2}{c}{ Simmental } \\
& Mean & SD & Mean & SD & Mean & SD & Mean & SD & Mean & SD \\
\hline 1 & 435 & 116 & 421 & 91 & 401 & 108 & 408 & 98 & 393 & 60 \\
2 & 416 & 116 & 374 & 67 & 406 & 111 & 364 & 78 & 370 & 55 \\
3 & 394 & 111 & 349 & 24 & 382 & 66 & 371 & 73 & 364 & 63 \\
4 & 407 & 115 & 366 & 84 & 370 & 31 & 374 & 70 & 373 & 78 \\
5 & 407 & 128 & 388 & 42 & 390 & 36 & 367 & 38 & 367 & 39 \\
Total & $416^{\text {ABCD }}$ & 117 & $387^{\mathrm{A}}$ & 77 & $393^{\mathrm{B}}$ & 91 & $381^{\mathrm{C}}$ & 81 & $377^{\mathrm{D}}$ & 618 \\
\hline
\end{tabular}

The same upper case letters in rows denote differences significant at $\mathrm{P} \leq 0.01$. 
Table 3

Percentage of normal and calving difficulties in subsequent calvings (Prozentsatz der Normal- und Schwergeburten bei nachfolgenden Abkalbungen)

\begin{tabular}{lccc|ccc|cccccccccc}
\hline \multirow{2}{*}{ Calvings } & \multicolumn{3}{c}{ Red Angus } & \multicolumn{3}{c}{ Salers } & \multicolumn{3}{c}{ Hereford } & \multicolumn{3}{c}{ Limousin } & \multicolumn{3}{c}{ Simental } \\
& num. & $\mathrm{n}$ & $\mathrm{d}$ & num. & $\mathrm{n}$ & $\mathrm{d}$ & num. & $\mathrm{n}$ & $\mathrm{d}$ & num. & $\mathrm{n}$ & $\mathrm{d}$ & num. & $\mathrm{n}$ & $\mathrm{d}$ \\
\hline 1 & 104 & 96.0 & 4.0 & 40 & 97.5 & 2.5 & 67 & 98.5 & 1.5 & 104 & 94.2 & 5.8 & 147 & 96.6 & 3.4 \\
2 & 104 & 98.1 & 1.9 & 44 & 100 & 0 & 47 & 95.8 & 2.1 & 77 & 98.7 & 0 & 112 & 99.1 & 0 \\
3 & 77 & 100 & 0 & 31 & 100 & 0 & 42 & 97.6 & 2.4 & 67 & 97.0 & 3.0 & 80 & 96.2 & 0 \\
4 & 58 & 100 & 0 & 21 & 100 & 0 & 31 & 96.8 & 3.2 & 58 & 96.6 & 1.7 & 54 & 98.1 & 0 \\
5 & 44 & 100 & 0 & 16 & 100 & 0 & 22 & 100 & 0 & 40 & 100 & 0 & 55 & 100 & 0 \\
6 & 29 & 100 & 0 & 13 & 100 & 0 & 8 & 100 & 0 & 17 & 100 & 0 & 44 & 95.4 & 2.3 \\
Total & 416 & 98.6 & 1.4 & 165 & 98.2 & 1.8 & 217 & 97.7 & 1.8 & 363 & 96.7 & 2.7 & 492 & 97.6 & 1.2 \\
\hline
\end{tabular}

num. $=$ number, $\mathrm{n}=$ normal calving in $\%, \mathrm{~d}=$ difficult calving in $\%$

Table 4

Percentage of abortions and stillbirths in subsequent calvings (Prozentsatz des Abortus und der Totgeburten bei nachfolgenden Abkalbungen)

\begin{tabular}{lcc|ccccccccc}
\hline \multirow{2}{*}{ Calvings } & \multicolumn{2}{c}{ Red Angus } & \multicolumn{2}{c}{ Salers } & \multicolumn{2}{c}{ Hereford } & \multicolumn{2}{c}{ Limousin } & \multicolumn{2}{c}{ Simental } \\
& $\mathrm{ab}$ & $\mathrm{sb}$ & $\mathrm{ab}$ & $\mathrm{sb}$ & $\mathrm{ab}$ & $\mathrm{sb}$ & $\mathrm{ab}$ & $\mathrm{sb}$ & $\mathrm{ab}$ & $\mathrm{sb}$ \\
\hline 1 & 0 & 0 & 0 & 0 & 0 & 3.0 & 0 & 1.9 & 0 & 1.4 \\
2 & 0 & 0 & 0 & 0 & 2.1 & 4.2 & 1.3 & 0 & 0.9 & 0 \\
3 & 0 & 0 & 0 & 0 & 0 & 4.8 & 0 & 1.5 & 3.8 & 0 \\
4 & 0 & 0 & 0 & 0 & 0 & 0 & 1.7 & 0 & 1.9 & 1.8 \\
5 & 0 & 0 & 0 & 0 & 0 & 0 & 0 & 2.5 & 0 & 0 \\
6 & 0 & 0 & 0 & 0 & 0 & 0 & 0 & 5.8 & 2.3 & 2.3 \\
Total & 0 & 0 & 0 & 0 & 0.5 & 2.8 & 0.6 & 0.5 & 1.0 & 0.2 \\
\hline
\end{tabular}

$\mathrm{ab}=$ abortions in $\%, \mathrm{sb}=$ stillbirth in $\%$

\section{Discussion}

Cows grow most intensively until they reach 4 years of age, with the growth rate dropping considerably past $4-5$ years of age. The highest body weight gains are recorded between the $2^{\text {nd }}$ and $3^{\text {rd }}$ year. A four-year-old cow attains approx. $89 \%$ of her final body weight. The target height is reached by the cows before they attain their maximum body weight, with three-year-old cows having $96 \%$ of a mature cow's height (ARANGO et al., 2002). MATTHES and RUDOLPH (1999) reported similar results on growth in different beef breeds. Similar average body weights for the same breeds of cows have been reported by LAMB et al. (1993) for the period between 1970 and 1984. Angus cows reached on average $580 \mathrm{~kg}$ in body weight, Hereford $598 \mathrm{~kg}$, Limousine $595 \mathrm{~kg}$ and Simmental $601 \mathrm{~kg}$. The present results do not differ substantially from those reported from the Polish herds (KLUPCZYŃSKI and MICIŃSKI, 2000; PIASECKI et al., 2000; POGORZELSKA and SZAREK, 2002).

The differences we have found between body weights of adult cows (after the $4^{\text {th }}$ calving) in all the studied breeds were not very high. In a majority of cases, those differences were from a few kilograms to $20-40 \mathrm{~kg}$. The highest body weights from the $3^{\text {rd }}$ and $4^{\text {th }}$ calvings were found in the Salers cows, as expected, since this particular breed is of a large size. The performance attained by the Hereford and Angus cows deserves special attention. Those cows, until recently called "small British breeds" in Poland, achieved from the $3^{\text {rd }}$ and $4^{\text {th }}$ calving (i.e. mature cows) larger body weights than Simmental, the breed considered as a one with a large body size. The Limousin cows body weights were similar to Red Angus, however lower than those of the Hereford cows. In a body-weight-competition ranking of cattle breeds, the Salers breed (with its highest body weight) would be ranked ahead of the others, followed by Hereford, jointly Limousin and Red Angus and Simmental. 
According to SULLIVAN et al. (1999), genetic differences between the breeds and relative rankings of particular breeds have been changing over the last decades due to differences in genetic trends. Those growing trends for the body weight were stronger for the light-weight breeds of cattle, which has resulted in diminishing differences between these and other, heavier breeds. Hereford cattle, for example, increased body weight during the period 1985-1995, and now these cattle at age of 365 days exhibit larger body weights than the Limousin. It has also been forecast that Angus cattle may by the year 2017 attain larger body weight at age than Charolais or Simmental.

The expected progeny difference (EPD) survey carried out in the USA during 19701984 has revealed that the fastest progress for the body weight at birth, at weaning, and in 365 days had been achieved for Hereford and Angus. Also positive, though not that spectacular changes were achieved by other breeds. For Simmental, however, weight at birth decreased, which implies that actual selection objectives may differ between breeds. Improved growth and a larger body frame size were the primary selection objectives for Angus and Hereford, while it was important to lower the weights at birth for Simmental in order to reduce calving difficulty with sustained positive trends for the weight at weaning and in 365 days (NOTTER and CUNDIFF, 1991).

The Hereford and Angus cattle still have an opinion in Poland of being "small breeds". As expected, the mean body weights of the cows measured in our study proved larger than those reported earlier by other authors. The cows analysed in this study were imported in 1995-1996, thus when the intensive selection had already improved their growth and increased their frame sizes as well as body weights. As a result of the fact the imported cows and their progeny were systematically sired by high-quality Canadian and American bulls, the genetic merit of the animals has been maintained. In our study, the average body weight of the Red Angus cows ranged from $484 \mathrm{~kg}$, on the $1^{\text {st }}$ calving, to $682.9 \mathrm{~kg}$, on the $6^{\text {th }}$ calving, whereas for the Hereford cows it was, respectively $504.3 \mathrm{~kg}$ and $690.1 \mathrm{~kg}$. According to previous reports (NADARAJAH et al., 1984; MARLOWE and MORROW, 1985; SACCO et al., 1990), body weights of 2- to 7-year-old Angus cows ranged from 411 to $510 \mathrm{~kg}$, whilst those of Hereford cows ranged between 402 and $523 \mathrm{~kg}$ (FIELD et al., 1988; SACCO et al., 1990). Later studies by GREGORY et al. (1992) revealed increasing average body weight, which in 2- to 7-year-old Hereford cows ranged from 428 to $579 \mathrm{~kg}$ and in Angus from 423 to $557 \mathrm{~kg}$. In the study by ARANGO et al. (2004), the mean body weights of 2-, 3-, 4-, 5and 6-year-old Angus cows were already 466, 523, 541, 548, and $542 \mathrm{~kg}$, respectively, and those for Hereford were 476, 545, 576, 579, and $604 \mathrm{~kg}$, respectively.

Comparing the mean body weights of the Red Angus vs. Hereford cows, we have observed that the latter were heavier after all calvings. Differences reaching 40-60 kg were found until the $3^{\text {rd }}$ calving, falling to $7-12 \mathrm{~kg}$ after the $5^{\text {th }}$ calving. FRAHM and MARSHALL (1985) reported that Hereford cows are characterised by larger body weights than Angus cows. Also according to GREGORY et al. (1992) Hereford cows were heavier than Angus cows, with the differences ranging from $5 \mathrm{~kg}$ (two-year-old cows) to $22 \mathrm{~kg}$ (7 years of age). SACCO et al. (1990) have found that Hereford cows between 3 and 4 years of age were heavier than Angus cows by as little as $6 \mathrm{~kg}$. According to ARANGO et al. (2002), on the other hand, Angus and Hereford cows attained similar weights, except for 6- and 7-year-old Angus cows, which were slightly larger than Hereford cows. 
Differences in the mean body weights of mature cows of the studied breeds are not very high, therefore we can assume that the body sizes of the breeds have rather been equalised, which confirms that the selection for larger frame sizes of Red Angus and Hereford cattle carried out for decades has been successful.

Selective breeding in beef cattle has been focusing on increasing the growth rates. However, whatever the production system, reproductive traits appear to be the most economically important in a beef cattle improvement program. In fact, reproductive traits dramatically affect productivity. Nevertheless, no suitable selection criterion exists due to the difficulty of finding easily measurable traits under paddock mating (the most frequent case in beef cattle) which are genetically related to reproduction. Calving interval is the chosen trait to measure cows' fertility. (GOYACHE and GUTIERREZ, 2001)

Calving interval after the first calving found in the present study was unsatisfactory. The parameter improved considerably after the $2^{\text {nd }}$ calving in the Simmental, Salers, and Limousin cows, and after the $3^{\text {rd }}$ calving in the Herefords. The Red Angus cows exhibited too long calving intervals after all calvings, which should be considered as unfavourable. Extension of subsequent calving intervals may have resulted from displaced calving dates; beef cows that calve late in the given year often maintain this date in the following year or do not conceive at all (PATTERSON et al., 1992). PRZYSUCHA et al. (2002) found the longest calving intervals being after the $1^{\text {st }}$ calving as well as the $4^{\text {th }}$ calving and those to follow. WERTH et al. (1996) reported that young beef cows have longer periods of postpartum anestrus than mature cows and frequently have calving intervals that are longer than 365 days. Cows at 2 years of age tend to have a longer postpartum interval to time of conception (SHORT et al., 1990). Two-year-old cows are still growing during gestation, and the fetus is also competing for nutrients. If the cow is stressed nutritionally, nutrient needs of the fetus are met first, and any of the dam's energy stores are subject to depletion. After calving, young cows must satisfy their own growth, maintenance, and lactation requirements, as well as replenish their own depleted energy stores before initiation of estrous cycles will occur (SHORT et al., 1990; WERTH et al., 1996). The calving intervals observed in our study were similar to those reported by other authors in other Polish herds of beef cattle (LITWIŃCZUK et al., 2001; POGORZELSKA et al., 1999).

The common opinion that the analysed breeds differ considerably in calving ease and mature body weight was not confirmed in this study, which implies that great changes have undergone in the success of the selection. In the early 1970s, as demonstrated by LASTER et al. (1973), calves sired by Charolais, Simmental and Limousin bulls experienced significantly more calving difficulty than those sired by Hereford and Angus bulls. No significant differences in percent calving difficulty were found among the Charolais, Simmental, Limousin. Hereford cows had more calving difficulty than Angus cows. Recent studies by ERIKSSON et al. (2004) have revealed that the Charolais and Hereford breeds, considered as extremes in terms of calving ease, were characterised by a very similar percentage of calving difficulties. The authors report that the total frequency of difficult calvings was $6.6 \%$ for Charolais and $6.2 \%$ for Hereford at first parity and $1.0 \%$ for Charolais and $1.2 \%$ for Hereford at later parities. The incidence of stillbirth was also higher in heifers $(5.9 \%$ for Charolais and $5.6 \%$ for Hereford) compared with older cows ( $1.8 \%$ for both breeds). 
Studies carried out on Polish herds (PIASECKI et al., 2000; LITWIŃCZUK et al., 2001; STENZEL et al., 2001) show that calving difficulties, depending on the breed and management system, may reach up to $8 \%$ of parturitions (2-4\% most frequently), while the mortality rate may range from $6 \%$ up to $14 \%$ under very extensive conditions, abortions percentage may reach $3.5 \%$, while the percentage of stillbirths may be $5 \%$. The highest incidence of calving difficulties was recorded in this study on the first calving. KRZYWDA et al. (2002) report that relatively highest rate of calving difficulties are observed with the first calving; however, such disturbances usually cease naturally or mere human assistance is needed.

Stillbirths and dystocias can result in direct losses due to calf mortality, dam mortality and premature culling, as well as indirect costs due to additional veterinary services, labour and treatment (MCDERMOTT et al., 1992; GOYACHE and GUTIERREZ, 2001). For dystocia, individual calf and dam factors have been reviewed by a number of authors (MEIJERING, 1984; MCDERMOTT et al., 1992). The size of the calf is considered to be the most important determinant (NAAZIE et al., 1989; BENNET and GREGORY, 2001; ERIKSSON et al., 2004).

A large calf in relation to the inlet pelvic dimensions of the cow is the most common cause of dystocia (NAAZIE et al., 1989) and is more important in heifers than in cows (MEIJERING, 1984). KOOTS et al. (1994) reported positive genetic correlations between birth weight and perinatal mortality, suggesting that in most studies, birth weight was larger than optimum. In a review presented high direct genetic correlations between birth weight and calving ease of -0.73 and -0.67 for cows and heifers, respectively. BENNETT and GREGORY (2001) reported direct and maternal genetic correlations of 0.81 and 0.34 , respectively, between birth weight and calving difficulty for beef cattle.

Calving difficulty and stillbirth generally have higher incidences in the first parity vs. later parities (MCDERMOTT et al. 1992; ERIKSSON et al., 2004). ERIKSSON et al. (2004) state that although the average birth weight of calves from heifers was 7 to $10 \%$ lower than for calves of later parity cows, heifers were also smaller than cows and the frequency of difficult calvings was considerably higher at first parity compared with later parities.

Posterior or abnormal presentations of the calf, weak labour, uterine torsion, and insufficient dilatation of the cervix are of importance especially in older cows (MEIJERING, 1984). According to MCDERMOTT et al. (1992), dystocia in cows was associated with calf sex, previous calving assistance, and large breed type and birth weight; however, in heifers difficult calvings were associated with large breed type and calf birth weight.

The present study has revealed that out of 15 stillborn calves, 7 passed through a difficult labour, whereas more than a half $(8$ calves) was born from normal parturitions. In several studies (BERGER et al., 1992; MCDERMOTT et al., 1992; ERIKSSON et al., 2004) more than half of the stillborn calves did not have difficult calvings. The causes of stillbirth for calves with easy or normal calvings are largely unknown (MEIJERING, 1984; DARGATZ et al., 2004).

The incidence of dystocia observed in this study should be considered low, which is a good news. Ranging between $1.2 \%$ and $2.7 \%$, calving difficulties were to a large extent due to the management system that allows the cows to move freely, but also due 
to a low body weight at birth, estimated in the study by PILARCZYK and WÓJCIK (2007) as ranging between $30.0-34.8 \mathrm{~kg}$ for heifer calves and 30.7-35.8 kg for bull calves. According to MCDERMOTT et al. (1992), dystocia rates were lowest for herds calving on pasture and increased through the barn/pasture, barn/yard and closed barn calving location categories. Stillbirths for both cows and heifers were associated with calving assistance, particularly hard assistance. However, a significant proportion of stillborn calves were delivered without assistance.

The breeder should always keep in mind while selecting for weight at birth that excessive body weight of the calf will lead to increased mortality at parturition, whereas lower body weight will be negatively reflected in the growth rate and, consequently, in the profitability of the production (BENNETT and GREGORY, 2001).

Although calf losses due to dystocia can probably be reduced by providing assistance at parturition, there is no clear means of preventing early-term abortions, late-term abortions, or stillbirths (KIRKPATRICK, 2002).

In typical beef herds, twins are a relatively unusual event. Reviews on the genetics of twinning (RUTLEDGE, 1975) suggest that twinning rate in beef breeds is typically less than $5 \%$. Increasing the incidence of twin births in cattle is one method to increase productivity of beef cattle. However, the opinion KIRKPATRICK (2002), twin birth is undesired by most beef producers for its association with a number of detriments, including lower perinatal calf survival and poorer cow reproductive performance. Regarding cow performance, twinning is associated with increased dystocia (due to malpresentation), increased incidence of retained placenta, greater frequency of abortion in twin gestation, and longer interval from parturition to first estrus.

To recapitulate, a comparison of the reproductive performance of the cows revealed large variations between the analysed breeds in terms of the calving interval. The best results were achieved by Simmental and Limousin, whereas Red Angus was the worst breed in this respect. An effect of subsequent calving on the calving interval was also demonstrated with the longest calving interval found after the $1^{\text {st }}$ calving and the shortest after the $3^{\text {rd }}$ calving, with a growing trend after subsequent calvings. The breeders are advised to pay particular attention to these critical periods. The most calving difficulty incidents were observed at the $1^{\text {st }}$ calving. During the analysed period, abortions and stillbirths accounted for $1 \%$ of pregnancies, except for the Hereford group where 2.8 $\%$ stillbirths were recorded. We have also noted a large percentage of twin births in the analysed herds, ranging from 0.5 to $3.5 \%$, the most among the Simmental cows. This has not, however, caused any decrease in reproductive performance of the cows of this breed. The parameters observed can be considered good, except for the long calving interval in the Red Angus cows. The fact that the cows have been systematically sired by prime-quality polled bulls from the USA or Canada allows presumption that the positive trends in the developing Polish beef cattle production will be maintained.

\section{References}

ARANGO, J.A.; CUNDIFF, L.V.; VAN VLECK, L.D.:

Breed comparisons of Angus, Charolais, Hereford, Jersey, Limousin, Simmental, and South Devon for weight, weight adjusted for body condition score, height, and body condition score of cows. J. Anim. Sci. 80 (2002), 3123-3132

ARANGO, J.A.; CUNDIFF, L.V.; VAN VLECK, L.D.:

Comparisons of Angus, Charolaise, Galloway, Hereford, Longhorn, Nellore, Piedmontese, Salers, and Shorthorn breeds for weight, weight adjusted for body condition score, height, and condition score of cows. J. Anim. Sci. 82 (2004), 74-84 
BENNETT, G.I.; GREGORY, K.E.:

Genetic (co)variances for calving difficulty score in composite and parental populations of beef cattle: I. Calving difficulty score, birth weight, weaning weight, and postweaning gain. J. Anim. Sci. 79 (2001), 45-51

BERGER, P.J.; CUBAS, A.C.; KOEHLER, K.J.; HEALEY, M.H.: Factors affecting dystocia and early calf mortality in Angus Cows and Heifers. J. Anim. Sci. 70 (1992), $1775-1788$

DÁKAY, I.; MÁRTON, D.; BENE, S.; KISS, B.; ZSUPPÁN, Z.; SZABÓ, F.: The age at first calving and the longevity of beef cows in Hungary. Arch. Tierz. 49 (2006), 417-425

DARGATZ, D.A.; DEWELL, G.A.; MORTIMER, R.G.:

Calving and calving management of beef cows and heifers on cow-calf operations in the United States. Theriogenology 61 (2004), 997-1007

ERIKSSON, S.; NÄSHOLM, A.; JOHANSSON, K.; PHILIPSSON, J.: Genetic parameters for calving difficulty, stillbirth, and birth weight for Hereford and Charolais at first and later parities. J. Anim. Sci. 82 (2004), 375-383

FIELD, T.G.; BRINKS, J.S.; TAYLOR, R.E.; TATUM, J.D.: Estimation of genetic parameters for mature weight in Hereford females. Proc. W. Sect. Am. Soc. Anim. Sci. 39 (1988), 30-32

FRAHM, R.R.; MARSHALL, D.M.: Comparisons among two- breed cross cow groups. I. Cow productivity and calf performance toweaning. J. Anim. Sci. 61 (1985), 844-855

FRELICH, J.; VORISKOVA, J.; KUNIK, J.; KVAPILIK, J.: Mast- und Schlachtleistungen von Bullen aus Gebrauchskreuzungen tschechischer Rinderrassen mit Fleischrindrassen. Arch. Tierz. 41 (1998), 533-544

GOLZE, M.:

Wachstum, Schlachtleistung und Schlachtkörperqualität von Weidemastkälbern aus der Mutterkuhhaltung mit Fleischrindrassen. Arch. Tierz. 44 (2001), 621-627

GOYACHE, F.; GUTIERREZ, J.P.: Heritability of reproductive traits in Asturiana de los Valles beef cattle breed. Arch. Tierz. 44 (2001), 489-496

GREGORY, K.E.; CUNDIFF, L.V.; KOCH, R.M.:

Breed effects and heterosis in advanced generations of composite populations on actual weight, adjusted weight, hip height, and condition score of beef cows. J. Anim. Sci. 70 (1992), 1742-1754

JAKUBEC, V.; SCHLOTE, W.; ŘÍHA, J.; MAJZLÍK, I.: Comparison of growth traits of eight beef cattle breeds in the Czech Republic. Arch. Tierz. 46 (2003), 143-153

KIRKPATRICK, B.W. Management of twinning cow herds. J. Anim. Sci. 80 (2002), E14-E18 (E. Suppl. 2).

KLUPCZYŃSKI, J.; MICIŃSKI, J.: Analysis of reproduction performance of Limousine cows. Ann. Warsaw Agricult. Univ. SGGW, Anim. Sci. 35 (2000), 82-90 [in Polish]

KOOTS, K.R.; GIBSON, J.P.; WILTON, J.W.: Analyses of published genetic parameter estimates for beef production traits. 2. Phenotypic and genetic correlations. Anim. Breed. 62 (1994), 825-853

KRZYWDA, W.; SZAREK, J.; GIL, Z.; ADAMCZYK, K.; BULECA, J.: The calvings of Limousin cows breed in Poland. Rocz. Nauk. Zoot. 15 (2002), 209-212

LAMB, M.A.; TESS, M.W.; ROBISON, O.W.: Evaluation of Mating Systems Involving Five Breeds for Integrated Beef Production Systems: IV. Accounting for Variability and Genetic Trends. J. Anim. Sci. 71 (1993), 587-594

LASTER, D.B.; GLIMP, H.A.; CUNDIFF, L.V.; GREGORY, K.E.: Factors affecting dystocia and the effects of dystocia on subsequent reproduction in beef cattle. J. Anim. Sci. 36 (1973), 695-705

LITWIŃCZUK, Z.; STANEK, P.; JANKOWSKI, P.: Influence of age and calving season of beef heifers on their further breeding and calf rearing results. Rocz. Nauk. Zoot. 28 (2001), 213-224 [in Polish]

MARLOWE, T.J.; MORROW, G.A.: Heritabilities and phenotypic, genetic and environmental correlations for weight, grade and condition of Angus cows. J. Anim. Sci. 60 (1985), 82-88

MATTHES, H.D.; RUDOLPH, E.: Beschreibung des Wachstums weiblicher Rinder verschiedener Rassen. Arch. Tierz. 42 (1999), 335-345

MCDERMOTT, J.J.; ALLEN, O.B.; MARTIN, S.W.; ALVES, D.M.: Patterns of stillbirth and dystocia in Ontario cow-calf herds. Can. J. Vet. Res. 56 (1992), 47-55

MEIJERING, A.: Dystocia and stillbirth in cattle. A review of causes, relations and implications. Livest. Prod. Sci. 11 (1984), 143-177 
NAAZIE, A.; MAKARECHIAN, M.; BERG, R.T.:

Factors influencing calving difficulty in beef heifers. J. Anim. Sci. 67 (1989), 3243-3249

NADARAJAH, K.; MARLOWE, T.J.; NOTTER, D.R.:

Growth patterns of Angus, Charolais, Charolais $\times$ Angus and Holstein $\times$ Charolais cows from birth to maturity. J. Anim. Sci. 59 (1984), 957-966

NOTTER, D.R.; CUNDIFF, L.V.:

Across-breed expected progeny differences: Use of within-breed expected progeny differences to adjust breed evaluations for sire sampling and genetic trend. J. Anim. Sci. 69 (1991), 4763-4776

NÚÑEZ-DOMINGUEZ, R.; VAN VLECK, L.D.; CUNDIFF, L.V.:

Breed comparisons for growth traits adjusted for within-breed genetic trend using expected progeny differences. J. Anim. Sci. 71 (1993), 1419-1428

PATTERSON, D.; CORAH, L.; BRETHOUR, J.; HIGGINS, J.; KIRACOFE, G.; STEVENSON, J.:

Evaluation of reproductive traits in Bos taurus and Bos indicus crossbred heifers: Relationship of age at puberty to length of the postpartum interval to estrus. J. Anim. Sci. 70 (1992), 1994-1999

PIASECKI, W.; GRODZICKA, M.; SLÓSARZ, J.:

The number of beef cattle herds and their performance test results. Ann. Warsaw Agricult. Univ. SGGW., Anim. Sci. 35 (2000), 191-196 [in Polish]

PILARCZYK, R.; WÓJCIK, J.:

Comparison of calf rearing results and nursing cow performance in various beef breeds managed under the same conditions in north-western Poland. Czech J. Anim. Sci. 52 (2007), 325-333

POGORZELSKA, J.; KIJAK, Z.; TARCZYŃSKI, R.:

Analysis of reproduction performance and the results of rearing the progeny of the Hereford cattle, imported from Denmark. Zesz. Nauk. Prz. Hod. 44 (1999), 389-395 [in Polish]

POGORZELSKA, J.; SZAREK, J.:

A comparison of the results of cow reproduction performance and calf Reading in two Hereford herds kept under various environmental conditions. Zesz. Nauk. Prz. Hod. 62 (2002), 193-202 [in Polish]

PRZYSUCHA, T.; GRODZKI, H.; CHARŁAMPOWICZ, A.; ZDZIARSKI, K.:

The effect of selected factors on growth rate of Limousine calves. Anim. Sci. Pap. and Rep. 20 (2002), 221-228

ROUGHSEDGE, T.; THOMPSON, R.; VILLANUEVA, B.; SIMM, G.:

Synthesis of direct and maternal genetic components of economically important traits from beef breedcross evaluations. J. Anim. Sci. 79 (2001), 2307-2319

RUTLEDGE, J.J.:

Twinning in cattle. J. Anim. Sci. 40 (1975), 803-815

SACCO, R.E.; BAKER, J.F; CARTWRIGHT, T.C.; LONG, C.R.; SANDERS, J.O.:

Measurements at calving for straightbred and crossbred cows of diverse types. J. Anim. Sci. 68 (1990), 3103-3108

SHORT, R.E.; BELLOWS, R.A.; STAIGMILLER, R.B.; BERARDINELLI, J.G.; CUSTER, E.E.

Physiological mechanisms controlling anestrus and infertility in postpartum beef cattle. J. Anim. Sci. 68 (1990), 799-816

STENZEL, R.; CHABUZ, W.; JANKOWSKI, P.; MROCZEK, A.:

Preliminary results of reproduction and rearing of calves in beef cattle herds. Zesz. Nauk. Prz. Hod. 55 (2001), 221-227 [in Polish]

SULLIVAN, P.G.; WILTON, J.W.; MILLER, S.P.; BANKS, L.R.:

Genetic trends and overlap derived from multiple-breed genetic evaluations of beef cattle for growth traits. J. Anim. Sci. 77 (1999), 2019-2027

WERTH, L.A.; AZZAM, S.M.; KINDER, J.E.:

Calving intervals in beef cows at 2, 3, and 4 years of age when breeding is not restricted after calving. J.

Anim. Sci. 74 (1996), 593-596

Received: 2007-02-05 Accepted: 2008-06-11

Corresponding author:

RENATA PILARCZYK, Ph.D.

Agriculture University

Department of Ruminant Science

Doktora Judyma 10

71-460 Szczecin

Poland

email: renata.pilarczyk@biot.ar.szczecin.pl 